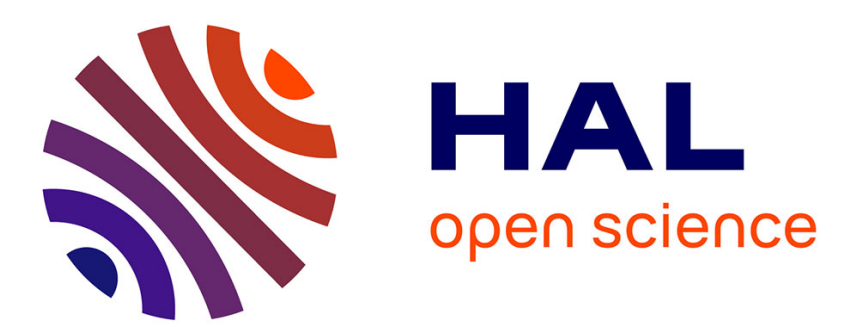

\title{
Effect of nutrient removal on radial growth of Pinus sylvestris and Quercus petraea in Southern Germany
}

Christian Zang, Andreas Rothe

\section{To cite this version:}

Christian Zang, Andreas Rothe. Effect of nutrient removal on radial growth of Pinus sylvestris and Quercus petraea in Southern Germany. Annals of Forest Science, 2013, 70 (2), pp.143-149. 10.1007/s13595-012-0238-8 . hal-01201459

\section{HAL Id: hal-01201459 \\ https://hal.science/hal-01201459}

Submitted on 17 Sep 2015

HAL is a multi-disciplinary open access archive for the deposit and dissemination of scientific research documents, whether they are published or not. The documents may come from teaching and research institutions in France or abroad, or from public or private research centers.
L'archive ouverte pluridisciplinaire HAL, est destinée au dépôt et à la diffusion de documents scientifiques de niveau recherche, publiés ou non, émanant des établissements d'enseignement et de recherche français ou étrangers, des laboratoires publics ou privés. 


\title{
Effect of nutrient removal on radial growth of Pinus sylvestris and Quercus petraea in Southern Germany
}

\author{
Christian Zang • Andreas Rothe
}

Received: 14 December 2011 / Accepted: 13 August 2012 /Published online: 12 September 2012

(C) INRA / Springer-Verlag France 2012

\begin{abstract}
- Context The rising demand of energy wood for heating purposes in Germany leads to concerns regarding the overexploitation of forests. A major aspect is the impact of whole-tree harvesting on long-term productivity of forest soils.

- Aims This study aimed to analyze the effects of nutrient removal on productivity using the historically prevalent practice of litter raking. Since there is a lack of controlled whole-tree harvesting experiments in Germany, we used litter raking as a surrogate management practice entailing the removal of nutrients from forest stands.

- Methods We used three sites with documented litter raking to analyze the effects of nutrient removal on productivity using dendroecological methods: two recent litter removal experiments in two Scots pine stands (Siegenburg and Burglengenfeld) and one oak stand (Eichhall) with documented historic litter raking. Basal area increment (BAI) and tree-ring characteristics were compared between periods with
\end{abstract}

Handling Editor: Gilbert Aussenac

Contribution of the co-authors C.Z. and A.R. designed the study. C.Z. performed the analysis with input from A.R. Both authors contributed to discussion, interpretation, and writing the paper.

\section{Zang $(\bowtie)$}

Chair of Ecoclimatology, Technische Universität München,

Hans-Carl-von-Carlowitz-Platz 2,

85354 Freising, Germany

e-mail: christian.zang@wzw.tum.de

\section{Zang}

Institute of Advanced Studies, Technische Universität München,

Lichtenbergstraße 2a,

85748 Garching, Germany

\section{A. Rothe}

Faculty of Forestry, University of Applied Sciences

Weihenstephan-Triesdorf,

Hans-Carl-von-Carlowitz-Platz 3,

85354 Freising, Germany litter raking and the preceding periods for both treatment and control plots.

- Results For the two Scots pine sites with a relatively short litter raking period, no effects of litter raking on BAI could be ascribed to nutrient removal. On the oak site with a longer history of litter utilization, the loss in BAI due to litter raking amounts to $22 \%$ during the period with active raking and to still $17 \%$ in the recovery period.

- Conclusions These results contribute to the still very limited understanding about the impact of whole-tree harvesting on forest productivity in Germany by laying down an upper limit of possible effects due to nutrient removal, as nutrient loss by litter raking tends to be higher than nutrient loss by whole-tree harvesting.

Keywords Nutrient removal $\cdot$ Productivity $\cdot$ Pine $\cdot$ Oak . Tree-rings

\section{Introduction}

Political stimuli for renewable energies and rising prices of fossil fuels entailed an increase in wood demand in Central Europe. For the last 10 years, felling rates in Germany have been increasing, from $39.5 \mathrm{Mm}^{3}$ in 2001 to $54.4 \mathrm{Mm}^{3}$ in 2010 with rising wood energy consumption being a substantial driver (German Federal Ministry of Food, Agriculture and Consumer Protection 2010). Besides the prevalent firewood use in private household, wood energy is increasingly used in municipal or private biomass heating plants, wood chip, or pellet heating systems. According to the German wood energy and pellet association, currently $15 \mathrm{M}$ household in Germany use wood for generating heat (Deutsches Pelletinstitut DEPI 2010). A further increase of wood demand is predicted in order to achieve the targets set in the national renewable energy action plan; further pressure on forests may also arise from the German decision to phase out nuclear power by 2022 . 
As a consequence, public is more and more concerned about an overexploitation of forests. One of the major aspects is the impact of whole-tree harvesting on longterm productivity of forest soils due to nutrient removal. In Central European forests, long-term historical experiences exist concerning the anthropogenic influence on the forest nutrient cycle. Litter raking - the removal of fresh litter and of the organic horizon for animal husbandry-which was a widespread practice especially on poor soils until World War II led to a strong degradation of forest soils. Since nutrient concentrations are much higher in leaves, twigs, and branches compared to the bole, the export of nutrients like N, P, Ca, Mg, and K may be up to three times higher for full tree harvest compared to removal of the bole only (Jacobsen et al. 2003). Already in the 1970s, forest ecologists indicated that whole-tree harvest may have serious and long-term adverse effects on nutrient cycling, especially on poor sites (Kreutzer 1979).

Most of the present concerns are based on nutrient budgets showing that nutrient removal by whole-tree harvesting can exceed nutrient input by precipitation and weathering, but direction and intensity of the effects strongly depend on the nutrient status of the site (Englisch and Reiter 2009; Meiwes et al. 2008). Since comprehensive data for nutrient removal, weathering rates, precipitation input, and seepage water output are rarely available, also simplified approaches based on nutrient storage in biomass and in the exchangeable fraction of the soil have been used. In most cases, only "base cations" $\mathrm{Ca}, \mathrm{Mg}$, and $\mathrm{K}$ have been assessed while other elements, especially $\mathrm{P}$, have not been considered due to large uncertainties concerning their availability in forest soils. Thus, considerations based on nutrient budgets can only indicate a possible threat of soil fertility due to nutrient removal, but do not allow a quantification of production loss. However, such information would be pivotal for management decisions with regard to sustainable use of forest biomass.

Unfortunately, our knowledge in this context is limited. While many fertilization studies investigated the relationship between nutrient additions on productivity (e.g., Bergh et al. 1999; Nohrstedt 2001), only few studies have measured possible production losses of forest crops due to nutrient removal. Intensive long-term experiments investigating the impact of whole-tree harvesting on tree growth have only been performed in Scandinavia (Helmisaari et al. 2011). For intensive litter raking, strong reductions in growth rates (height and volume) have been documented on poor soils (Fiedler et al. 1962) and the strong increase of productivity of pine in Southern Germany (Küsters 2002) in the second half or the twentieth century has been explained with recovery of soils after the termination of litter raking. For nutrient removal by whole-tree harvesting, several studies mostly originating from Northern Europe indicate a loss of productivity between 0 and $15 \%$ (Helmisaari et al. 2011; Jacobson et al. 2000; Proe et al. 1996; Sterba 1988). However, effects vary widely depending on soil type, tree species, and intensity and timing of nutrient removal. Particularly in Central Europe with highly variable forest conditions, available data are insufficient for a quantitative assessment of productivity losses due to nutrient removal. Additionally, anthropogenic nitrogen deposition has strongly altered nutrient status of forest soils in Central Europe and effects of nutrient removal on nitrogen limited sites presumably differ from sites with a moderate to high $\mathrm{N}$ deposition.

While a comprehensive set of field experiments has been established in Scandinavia (Helmisaari et al. 2011), no scientific experiments are available for analyzing the influence of nutrient removal on productivity in Germany. Practical harvesting operations usually are not documented well enough for scientific analysis. Furthermore, intensive whole-tree harvesting in Germany only started some years ago and time may have been too short for generating significant effects. Therefore, we used three sites with documented litter raking in order to analyze the effects of nutrient removal on productivity using dendroecological methods. We hypothesized that nutrient removal affected soil productivity reflected by a threefold response in radial growth patterns:

1. A reduction in basal area increment (BAI) as a response to decreased nutrient availability

2. An increase in mean sensitivity (i.e., an increase in yearto-year variability) of tree growth reflecting an increasing influence of external factors on tree growth

3. A decrease in serial autocorrelation of tree ring growth reflecting a decrease in the trees' buffer capacity.

\section{Material and methods}

\subsection{Sampling sites}

Two litter removal experiments in Scots pine stands and one sessile oak stand with documented historic litter removal were selected for data acquisition. All stands are located in Southern Germany on acid soils: the sessile oak stand in the Eichhall Nature Reserve in the Spessart Mountains and the Scots pine stands in Siegenburg and Burglengenfeld (see Table 1). The two pine stands are relatively young and single-layered monocultures, while the nearly 400 -year-old oak stand is two-layered with beech understorey (Table 2).

In Eichhall, historic litter removal has been documented seven times in the period 1900-1946 (1900, 1907, 1918, 1924, 1932, 1943, and 1946). In Siegenburg, the historic litter removal ended in 1950 and was started again as a measure of landscape conservation in 1996 with yearly 
Table 1 Site characteristics

\begin{tabular}{lllllll}
\hline Site & Latitude [N] & Longitude [E] & Elevation [m asl] & $T_{\text {mean }}\left[{ }^{\circ} \mathrm{C}\right]$ & $P_{\text {mean }}[\mathrm{mm}]$ & Soil type/geology \\
\hline Siegenburg & 48.75 & 11.83 & 400 & 8.2 & 640 & $\begin{array}{c}\text { Dystric Cambisol/Holocene aeolian } \\
\text { sand deposit }\end{array}$ \\
Burglengenfeld & 49.17 & 12.02 & 390 & 7.4 & 620 & $\begin{array}{c}\text { Dystric Cambisol/Cretaceous sand deposit } \\
\text { Dichhall }\end{array}$ \\
\hline
\end{tabular}

Mean temperature $T_{\text {mean }}$ and mean precipitation sum $P_{\text {mean }}$ are given for the period 1950-2007

recurrence. In Burglengenfeld, historic litter removal ended around 1950 as well and was started again in 1999 for conservation purposes. For each of the sites, adjacent stands without litter removal were used as control plots. Soil types were identical on the litter-raked sites and on the control plots. Litter raking had no visible effects on soil morphology in the mineral soil but was clearly reflected in a reduced thickness of the forest floor. Although the quantity of nutrients removed has not been documented at any site, it can be assumed that large quantities of nutrients have been lost. Assuming yearly litter removals of $3 \mathrm{t}$ $\mathrm{ha}^{-1}$ for pine and $7 \mathrm{tha}^{-1}$ for oak per event (Ebermayer 1876), at minimum $300 \mathrm{~kg} \mathrm{~N} \mathrm{ha}^{-1}$ and a similar quantity of base cations $(\mathrm{K}+\mathrm{Ca}+\mathrm{Mg})$ have been removed at the two pine sites within 10 years. At the oak site, nutrient loss was in a magnitude of $1,000 \mathrm{kgha}^{-1}$ for both $\mathrm{N}$ and base cations within 50 years.

\subsection{Tree sampling and tree-ring measurement}

On each site, 10 to 14 vital and undamaged dominant trees were selected for treatment and control plots. Each tree was cored two times at breast height, from northwestern and southeastern direction. That way, the trees were cored $45^{\circ}$ displaced from the main wind direction to prevent bias in diameter estimation due to reaction wood. For coring, a drilling machine (BDF 452 RFE, Makita, Anjo, Aichi, Japan) was used in conjunction with hardwood corers (Suunto, Finland) or softwood corers (Haglöfs, Sweden). For transport, drying, and storage purposes, cores were put into specially constructed groove boards.

The increment cores of each tree were mounted and smoothed with a chisel. Ring widths were measured to the nearest $0.01 \mathrm{~mm}$ on each core using a measuring table (LINTAB 5; Rinntech, Heidelberg, Germany) with a stereoscope (MZ 6; Leica, Wetzlar; Germany) and the TSAP-Win software package (Rinn 2003). Crossdating accuracy was checked both visually by on-screen curve comparison in TSAP-Win and statistically using program COFECHA (Holmes 1983).

\subsection{Statistical analysis}

To compare radial growth between treatment and control plots, the series of corresponding tree-ring widths were transformed into series of BAI, based on the assumption that constant radial growth is expressed by constant ring area increment rather than constant diameter increment (Biondi and Qeadan 2008). This rationale has been affirmed by several studies on tree mortality (Bigler and Bugmann 2004; Bigler et al. 2006) and drought impact on tree growth (Piovesan et al. 2008; Kohler et al. 2010).

To identify differences in tree growth, mean BAI was compared between treatment and control plots for a pretreatment period and the treatment period. As pretreatment period, a time frame preceding the experimental (Siegenburg and Burglengenfeld) or historic (Eichhall) litter removal with identical length to the treatment period was chosen for each case (Table 3). BAI was averaged for the period prior to litter raking for each tree on both control plots and plots with posterior litter raking to obtain a reference average growth rate $\left(\mathrm{BAI}_{\mathrm{R}}\right)$. The same was done for the period of litter raking to obtain an average growth rate during the treatment $\left(\mathrm{BAI}_{\mathrm{T}}\right)$. The ratio $\mathrm{BAI}_{\mathrm{T}} / \mathrm{BAI}_{\mathrm{R}} \times 100$ then gives the relative change in $\mathrm{BAI}$ after litter raking has started. Differences in this relative change among the sites with litter raking and the respective control plots have been assessed using two-sided $t$ tests. As in Eichhall the litter raking stopped in 1946, a considerable time span is available for studying the recovery of the raked plot in comparison to the plot without litter raking. Here, an additional time span of equal length (1956-2000) was chosen for the recovery period.
Table 2 Stand characteristics (from 2009 for Burglengenfeld and Eichhall and from 2005 for Siegenburg)

\begin{tabular}{llllll}
\hline Site & Tree species & $\begin{array}{l}\text { Standing volume } \\
{\left[\mathrm{m}^{3} / \mathrm{ha}^{-1}\right]}\end{array}$ & $\begin{array}{l}\text { Mean diameter } \\
{[\mathrm{cm}]}\end{array}$ & $\begin{array}{l}\text { Mean height } \\
{[\mathrm{m}]}\end{array}$ & $\begin{array}{l}\text { Mean age } \\
{[\mathrm{a}]}\end{array}$ \\
\hline Siegenburg & Scots pine & 337 & 30 & 21 & 60 \\
Burglengenfeld & Scots pine & 298 & 34 & 24 & 94 \\
Eichhall & Sessile oak & 750 & 63 & 32 & 375 \\
\hline
\end{tabular}


Mean sensitivity (MS) and autocorrelation (AC) of BAI were calculated for pretreatment and treatment periods and compared using two-sided $t$ tests. The sensitivity $S_{i+1}$ for a year $i+1$ is a measure of local relative variability in tree growth, defined as $S_{i+1}=2\left(x_{i+1}-x_{i}\right)\left(x_{i+1}+x_{i}\right)^{-1}$. Consequentially, MS is calculated as arithmetic mean of $S_{i}$. The amount of autocorrelation has been obtained by considering the BAI series $\mathrm{AR}(n)$ processes, with order $n$ chosen via Aikaike's information criterion (Venables and Ripley 2002). All computations have been performed using R 2.13.0 (R Development Core Team 2011).

\section{Results}

\subsection{Tree age}

No significant differences in tree ages between treatment and control plots were found for Burglengenfeld and Eichhall. At Siegenburg, trees in the control plot were about 8 years older on average (Table 3 ).

\subsection{Long-term growth trends}

In all three cases, long-term growth trends are similar for raked and unraked plots (Fig. 1). At Eichhall, the BAI development of oak diverges at the end of the series, with a stronger increase in BAI on the raked plot from the 2000 onwards.

\subsection{Mean sensitivity and autocorrelation}

No consistent change in MS associated with litter raking could be detected (Table 3). In Siegenburg, the plot with litter raking exhibited a significantly greater MS after the raking started. In Eichhall, a significant difference in MS in the recovery period was found, with a higher MS on the control plot.

No consistent trend in a change in $\mathrm{AC}$ could be found (Table 3). In Burglengenfeld, the plot with litter raking depicted a significant increase in AC after raking started, whereas for Eichhall, a significant increase in $\mathrm{AC}$ was found for the control plot only for the treatment period. For the recovery period, both raked plot and control plot AC increased significantly in comparison to the time before litter raking started.

\subsection{Changes in BAI associated to litter raking}

For all three sites, changes in BAI due to litter raking were not significant (Fig. 2). At the Siegenburg and Burglengenfeld Scots pine sites, even a slight relative increase in BAI was observed on the raked sites. Thus, a negative impact of litter

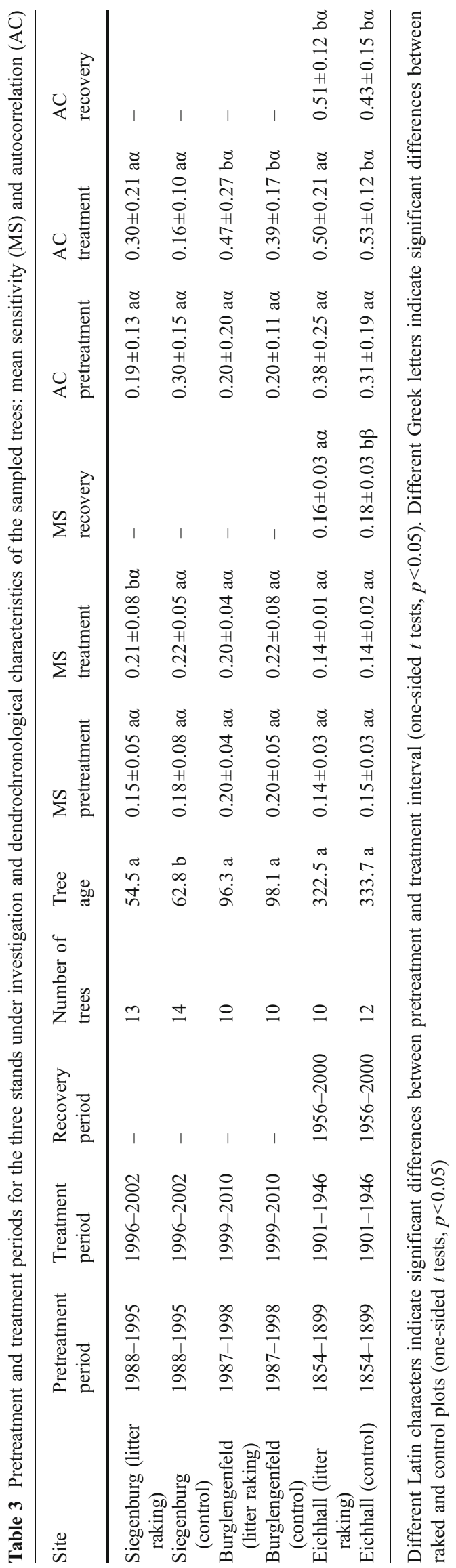




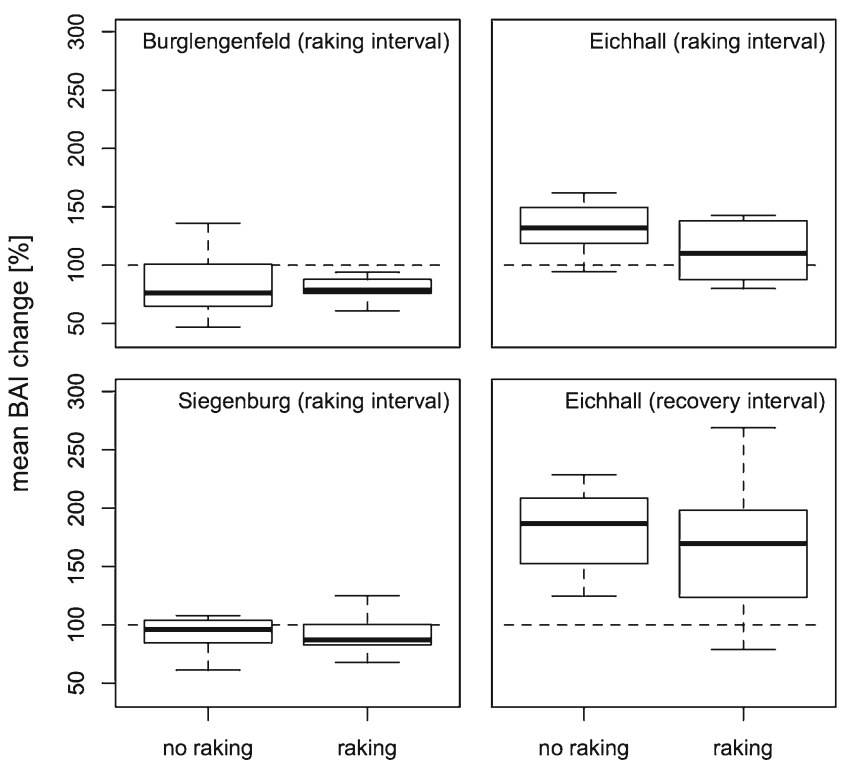

Fig. 1 Comparison of basal area increment for stands with and without litter raking at the different sites. Basal area increment is shown as 5year moving average

raking on basal area growth during the investigated time span can be excluded for these two sites. At the Eichhall oak site, median BAI at the raked site was about $22 \%$ less compared to the control plot indicating a negative growth effect by nutrient removal. The assumption is confirmed by a reduced difference between both plots during the recovery period. During the recovery period, median BAI was still $17 \%$ less on the litter-raked sites which can be interpreted as a longlasting effect of nutrient removal. However, variability between individual trees was high and the effects were not significant at the $p=0.05$ level. Thus, the negative growth effect can only be interpreted as a tendency albeit a $22 \%$ reduction is a strong production loss from a forest management point of view.

\section{Discussion}

\subsection{Raking effect on tree-ring statistics}

An effect of anthropogenic nitrogen and pollutant input on the variance of tree-ring width has been described for Pinus sylvestris in Lithuania (Juknys et al. 2002), rendering trees more susceptible to natural external factors. In our study on all three sites, increases in MS from the pretreatment to the treatment period could be observed, on both control and raked plots (significant only for Siegenburg). This indicates an increase in MS that is associated with tree aging rather than nutrient shortage. An increase of MS with increasing tree age has also been found for Pinus cembra and Larix decidua (Carrer and Urbinati 2004).
Fig. 2 Comparison of mean BAI changes relative to the reference time intervals before litter raking $(=100 \%)$ for control and treatment plots

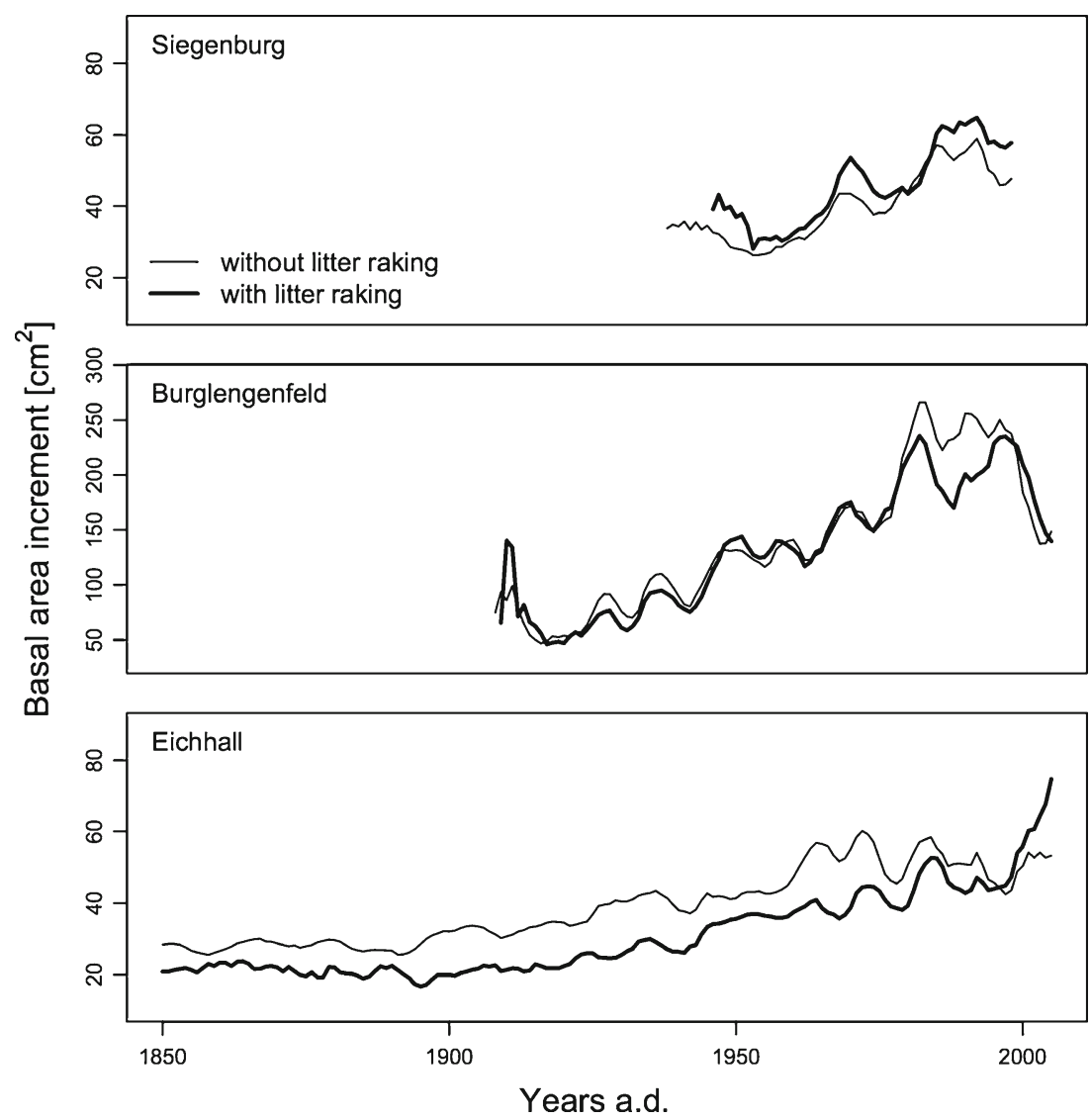




\subsection{Raking effect on basal area increment}

For both pine stands, no effect of litter raking on BAI was obvious. One explanation could be that the time span of litter raking at Siegenburg and Burglengenfeld was too short to yield significant effects of nutrient removal on tree growth. At both sites, nutrient removal has been performed for about 10 years only. In Scandinavian investigations, growth reaction in pine stands after whole-tree harvest was small in the first 10-year period and significantly increased later on (Helmisaari et al. 2011). Sayer (2006) showed in a meta-analysis of litter removal experiments that-across species - a reduction in growth rates generally becomes apparent after about 15 years. Furthermore, pine is a tree species well adapted to poor soils and has the capacity of efficient retranslocation of nutrients (Helmisaari 1992). Therefore, growth effects concerning nutrients tend to be smaller compared to spruce. Another reason for the missing growth effect could be that nitrogen deposition has compensated nutrient removal of litter raking. In fertilization trials, N usually was the limiting nutrient (Nohrstedt 2001), and in the above-mentioned whole-tree harvesting study, also nitrogen has been identified as the main limiting factor (Helmisaari et al. 2011). In Central European forests, nitrogen deposition - which is usually between 10 and $20 \mathrm{kgha}^{-1}$ in Central European forests (Emmett 2007) - may have compensated nitrogen removal by litter raking. We assume that in this case, other nutrients will become a limiting factor in the long run. At the Siegenburg site, foliar nutrient concentrations were measured in 2002, i.e., 7 years after litter raking had started (Beer 2004, unpublished). Nitrogen concentrations of pine needles at the raked plot tended to be higher than on the control plot ( 15.7 vs. $\left.15.0 \mathrm{mgg}^{-1}\right)$ and in a range of sufficient supply. $\mathrm{Mg}$ and $\mathrm{K}$ foliar concentrations were also in a sufficient range, but concentrations tended to be lower at the raked plot than on the control plot (5.0 vs. $5.6 \mathrm{~m} \mathrm{~K} \mathrm{~g} \mathrm{~g}^{-1}$ and 0.9 vs. $1.0 \mathrm{mg} \mathrm{Mg} \mathrm{g}^{-1}$ ) indicating a potential future threat. These findings are in line with Hofmeister et al. (2008) who found no decrease in foliar N for Picea abies, but in foliar $\mathrm{Mg}$ and $\mathrm{K}$ due to litter removal.

At the oak site with at least 50 years of litter raking, we observed a decrease in BAI of about $22 \%$ in comparison to the control plot. The median BAI change from the pretreatment to the treatment period suggests a stronger increase in BAI on the non-raked site, and this effect is still visible to a smaller extent in the recovery interval after raking had eventually stopped. Consequentially, litter removal appears to result in a delayed, but long-lasting impact on tree growth. Although average productivity loss was about $22 \%$, the effect was not significant due to the high variability of individual tree reaction. Unfortunately, the experimental plots were too small (between 0.07 and $0.11 \mathrm{ha}^{-1}$ for the raked plots) to sample more trees. Tree-ring width is a complex signal integrating different effects on tree growth, and distinct tree reactions are influenced by the individual genotype. A strong variability of individual tree-ring width was also observed when analyzing the influence of drought effects on commercial tree species (Zang et al. 2011).

\subsection{Implications for whole-tree harvesting}

While whole-tree harvesting is increasingly popular for biomass use, our knowledge about possible negative impacts on productivity is still limited. Unfortunately, only very few studies investigated the impact of whole-tree harvesting on forest productivity in Central Europe (Sterba 1988). It is clear that the effects depend on tree species and site factors. Even under relatively homogeneous conditions in Scandinavia, there was a strong variability between individual sites (Helmisaari et al. 2011). Since there is lack of controlled whole-tree harvesting experiments, we used litter raking experiments in order to assess the impact of nutrient removal on productivity. However, the comparison of litter raking to whole-tree harvesting is not straightforward. In whole-tree harvesting, leaves and twigs are typically removed together with the timber. So, in this case, fresh plant material with original nutrient stock is removed from the stands. On the opposite, litter consists of plant material whose nutrients have been retranslocated and therefore has a considerably lower concentration in nutrients (Helmisaari et al. 2011). However, biomass loss is high for litter raking since at least parts of the forest floor are removed and return period is frequent. As a net effect, nutrient exports tend to be lower for whole-tree harvesting compared to litter raking (Kreutzer 1979; Kreutzer 1972). Therefore, litter raking experiments can be considered as an upper limit of possible effects caused by whole-tree harvesting. As our quantitative knowledge in this context is still limited for Central Europe and large-scale experiments are lacking, we would like to invite other researchers to publish also smaller and sometimes only partial studies in order to contribute to a larger picture.

\section{Conclusions}

Nutrient removal may have serious negative impacts on forest productivity. However, effects strongly depend on tree species, site conditions, and duration and frequency of nutrient removal. Due to the increasing use of forest biomass as a fuel, whole-tree harvesting is becoming a standard management procedure. In order to maintain the long-term productivity of forest ecosystems, scientifically based recommendations for forest management are indispensable. According to our results, short or infrequent episodes of litter removal may not be strong enough to reduce pine 
growth significantly, especially in a situation characterized by high anthropogenic nitrogen deposition. On the other hand, our findings corroborate the wide experience that intensive and long-lasting nutrient removal affects forest productivity strongly and persistently. From our results, we infer that frequent and intensive whole-tree harvesting is likely to decrease forest productivity. However, current knowledge in Central Europe is insufficient for a quantitative assessment.

Acknowledgments We thank Axel Göttlein for his recommendations concerning the experimental sites and the former students Alexandra Schade, Michael Frank, Philipp Wolf, and Michelangelo Olleck for their strong commitment performing the field work. We also thank Erwin Dreyer and three anonymous reviewers for their comments that improved the paper. C.Z. has been funded by the Institute for Advanced Study of the Technische Universität München.

\section{References}

Bergh J, Linder S, Lundmark T, Elfving B (1999) The effect of water and nutrient availability on the productivity of Norway spruce in northern and southern Sweden. For Ecol Manag 119:51-62

Bigler C, Bugmann H (2004) Assessing the performance of theoretical and empirical tree mortality models using tree-ring series of Norway spruce. Ecol Mod 174:225-239

Bigler C, Bräker O, Bugmann H, Dobbertin M, Rigling A (2006) Drought as an inciting mortality factor in Scots pine stands of the Valais, Switzerland. Ecosystems 9:330-343

Biondi F, Qeadan F (2008) A theory-driven approach to tree-ring standardization: defining the biological trend from expected basal area increment. Tree-Ring Bull 64:81-96

Carrer M, Urbinati C (2004) Age-dependent tree-ring growth responses to climate in Larix decidua and Pinus cembra. Ecology 85:730-740

Deutsches Pelletinstitut DEPI (2010) Gesamtbestand an Pelletheizungen in Deutschland. http://www.depi.de/download/grafiken/ Pelletheizungen-in-Deutschland.jpg. 7 Nov 2011

R Development Core Team (2011) R: a language and environment for statistical computing. R Foundation for Statistical Computing, Vienna, Austria. ISBN 3-900051-07-0, http://www.R-project.org/

Ebermayer E (1876) Die gesamte Lehre von der Waldstreu. Springer, Berlin

Emmett BA (2007) Nitrogen saturation of terrestrial ecosystems: some recent findings and their implications for our conceptual framework. Water, Air, \& Soil Poll 7:99-109

Englisch M, Reiter R (2009) Standörtliche Nährstoff-Nachhaltigkeit bei der Nutzung von Wald-Biomasse. BFW-Praxisinformationen 18:13-15

Fiedler HJ, Fiedler E, Hoffmann F, Hohne H, Sauer G, Thomasius H (1962) Auswertung eines Streunutzungsversuches von H. VATER aus dem Jahre 1912. Arch f Forstw 11:1

German Federal Ministry of Food, Agriculture and Consumer Protection (2010) Statistisches Jahrbuch 2010, Kapitel G.
Forstwirtschaft. 418. Holzeinschlag nach Holzarten und Verwendung.

Helmisaari HS (1992) Nutrient retranslocation within the foliage of Pinus sylvestris. Tree Phys 10:45-58

Helmisaari HS, Hanssen KH, Jacobson S, Kukkola M, Luiro J, Saarsalmi A, Tamminen P, Tveite B (2011) Logging residue removal after thinning in Nordic boreal forests: long-term impact on tree growth. For Ecol Manag 261:1919-1927

Hofmeister J, Oulehle F, Krám P, Hruška J (2008) Loss of nutrients due to litter raking compared to the effect of acidic deposition in two spruce stands, Czech Republic. Biogeochemistry 88:139-151

Holmes R (1983) Computer-assisted quality control in tree-ring dating and measurement. Tree-Ring Bull 43:69-78

Jacobsen C, Rademacher P, Meesenburg H, Meiwes KJ (2003) Gehalte chemischer Elemente in Baumkompartimenten-Literaturstudie und Datensammlung. Berichte des Forschungszentrums Waldökosysteme, Reihe B 69.

Jacobson S, Kukkola M, Mälkönen E, Tveite B (2000) Impact of whole-tree harvesting and compensatory fertilization on growth of coniferous thinning stands. For Ecol Manag 129:41-51

Juknys R, Stravinskiene V, Vencloviene J (2002) Tree-ring analysis for the assessment of anthropogenic changes and trends. Environ Monit Assess 77:81-97

Kohler M, Sohn J, Nägele G, Bauhus J (2010) Can drought tolerance of Norway spruce (Picea abies (L.) Karst.) be increased through thinning? Eur J For Res 129:1109-1118

Kreutzer K (1972) Über den Einfluß der Streunutzung auf den Stickstoffhaushalt von Kiefernbeständen (Pinus silvestris L.). Forstwissenschaftliches Centralblatt 91:263-270

Kreutzer K (1979) Ökologische Fragen zur Vollbaumernte. Forstwissenschaftliches Centralblatt 98:298-308

Küsters E (2002) Wachstumtrends der Kiefer in Bayern. PhD-Thesis, Technische Universität München, Munich, Germany.

Meiwes KJ, Asche N, Block J, Kallweit R, Kölling C, Raben G, von Wilpert K (2008) Potenziale und Restriktionen der Biomassenutzung im Wald. AFZ-Der Wald 63:598-604

Nohrstedt HO (2001) Response of coniferous forest ecosystems on mineral soils to nutrient additions: a review of Swedish experiences. Scand J For Res 16:555-573

Piovesan G, Biondi F, Filippo A, Alessandrini A, Maugeri M (2008) Drought-driven growth reduction in old beech (Fagus sylvatica L.) forests of the central Apennines, Italy. Global Change Biol $14: 1265-1281$

Proe M, Cameron A, Dutch J, Christodoulou X (1996) The effect of whole-tree harvesting on the growth of second rotation Sitka spruce. Forestry 69:389-401

Rinn F (2003) TSAP-Win - time series analysis and presentation for dendrochronology and related applications. Germany, Heidelberg

Sayer EJ (2006) Using experimental manipulation to assess the roles of leaf litter in the functioning of forest ecosystems. Biol Rev 81:1-31

Sterba H (1988) Increment losses by full-tree harvesting in Norway spruce (Picea abies). For Ecol Manag 24:283-292

Venables WN, Ripley BD (2002) Modern applied statistics with S. Springer, New York

Zang C, Rothe A, Weis W, Pretzsch H (2011) Zur Baumarteneignung bei Klimawandel: Ableitung der Trockenstress-Anfälligkeit wichtiger Waldbaumarten aus Jahrringbreiten. Allgemeine Forst- und Jagdzeitung 182:98-112 